
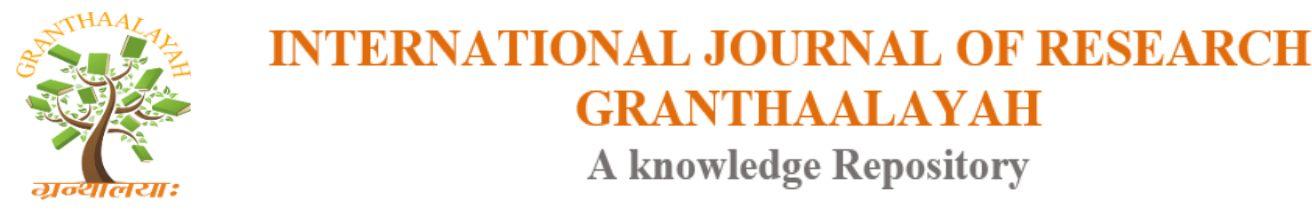

Management

\title{
RELATIONSHIP BETWEEN GENERATIONAL DIFFERENCES AND EMPLOYEE RETENTION IN KENYAN TELECOMMUNICATIONS FIRMS
}

\author{
Ogolla D.A. *1, Kidombo H. ${ }^{* 2}$, Senaji T.A. *3 \\ ${ }^{1}$ School of Business and Economics, Kenya Methodist University, Kenya \\ ${ }^{2}$ Department of Instructional Design Open, Distance and e-learning Campus University of \\ Nairobi, Kenya \\ ${ }^{3}$ Department of Business Administration, Kenya Methodist University, Kenya
}

\begin{abstract}
Employee retention is a major challenge facing many organizations today. The understanding of Generational differences at the workplace has been identified as a key requirement in implementing measures for effective employee retention. Within the telecommunications firms in Kenya, the problem of employee retention is a major challenge to the telecommunications firms. This paper thus examines the effect of generational differences on the retention of engineers in telecommunications firms in Kenya from the generational theory and generational cohorts theory perspective. This study used the cross-sectional and descriptive survey research design. Data were analyzed using descriptive and inferential statistics. We found that there exist a statistically significant variation in employee retention across the generational cohorts as observed through employee engagement, job satisfaction and organizational commitment (continuance commitment, affective commitment and normative commitment). These findings extend the theory regarding employees' retention and have implication for employee retention practices which should be differentiated across the generational cohorts.
\end{abstract}

Keywords: Generational Differences; Retention; Telecommunications Firms; Kenya.

Cite This Article: Ogolla D.A., Kidombo H., and Senaji T.A.. (2018). "RELATIONSHIP BETWEEN GENERATIONAL DIFFERENCES AND EMPLOYEE RETENTION IN KENYAN TELECOMMUNICATIONS FIRMS.” International Journal of Research - Granthaalayah, 6(7), 348-367. https://doi.org/10.29121/granthaalayah.v6.i7.2018.1315.

\section{Introduction}

Employee retention is a key concern to many organizations today as organizations grapple with the challenge of retaining their key talents. Skills and knowledge possessed by employees have been considered as key divers required by organizations to achieve competitive advantage (Michington, 2010, Walker 2011). In this era of competition, employers must devise methods of retaining their key talents if they have to survive in any industry (Gurumani, 2010). 
In the $21^{\text {st }}$ century, organizations have recognized that in order to succeed in achieving competitive advantage, they must have the best and stable workforce in their employment (Guest, 2011). To achieve this objective, organizations need to institute measures that will engage and retain their most valued employees. However, very few organizations have adequate supply of talent they need to match their needs (Greenblatt, 2002). Many organizations are facing scarcity of talents, hence the 'war for talents' (Capelli, 2000).

According to global human resource and talent management survey (Deloitte, 2014), executives all over the world are faced with 'talent paradox' as specialized skills are increasingly becoming scarce thereby creating urgent need for building strong workforce capability and retention. Global competition is even tougher for critical skills like software engineers, with companies struggling to keep up with the demand. This is making software firms to increasingly find ways of retaining their employees. The survey established that the capability gap is far broader among these companies hence need for employee retention. In addition, as competition continue to intensify in almost every industry and as many strategies being replicated across organizations, it is increasingly being recognized that people skills are the main differentiator that can help organizations achieve competitive advantage (Bell, 2013). Thus to remain competitive, organizations must develop strategies to retain their key talents. This study identified a gap on generational differences as a result of age and thus sought to establish retention strategies used by organizations for different age groups or cohorts of employees. Engineering skills is regarded as a critical for technology firms. Due to the scarcity nature of this kind of skill, many firms cannot adequately meet the demand for engineers (Hasna and Clark, 2009). The skills gap of engineers is a result of few graduating engineers who can march the demand hence the problem of engineers' retention (Davenport, 2006).

A number of studies carried out in the United States, United Kingdom and Australia, among other countries in the developed world found a positive relationship between generational differences and employee retention. However, there is a paucity of research in Kenya in this area. Studies by Delloite (2014) established that retaining skilled staff in a competitive environment is the biggest challenge facing human resource managers in Kenya today. The research by Delloitte (2014) further revealed that $80 \%$ of human resource managers who responded in the survey indicated that employee retention is a key priority to them in the management of their human capital management. In the study, 52\% of the companies surveyed also indicated that they were not prepared to cope with the challenge of retention. This suggest that the problem of employee retention is a key challenge facing many organizations in Kenya currently.

Telecommunication sector in Kenya is facing a critical shortage of engineers. Many of such firms are grappling with the problem of retaining the few engineers in their employment as there is constant poaching among competing companies (Ernst and Young, 2013). This has created the need for retention of Engineers within the Telecommunications sector in Kenya. The research tested the hypothesis:

$\mathrm{H}_{01}$ There is no significant difference in employee retention across generational cohorts in telecommunications firms in Kenya. 


\section{Theory and Hypothesis}

This study draws from the generational theory and the generational cohorts' theory to hypothesize on the relationship between generational differences and employee retention within telecommunication firms in Kenya.

\section{Generational Theory}

The study of generations is deeply rooted in history. It dates back to previous studies carried out in the ancient Greeks which pointed out the existence of four generational periods in history (Golden, Silver, Bronze and Iron) (Burnett, 2011 as cited in Joshi et al., 2011; Nash, 1978). The studies found that generations were marked by the cyclical nature of life, death and afterlife (Redford, 2003). It was believed that people went through various stages in the life cycles giving an indication of different generations. According to Joshi et al. (2011), generations were defined by distinct stages separating one generation from another. However, modern understanding of generations view it as a straight line moving from one generation to the next in a cyclical manner (Adam, 1990; Joshi et al., 2011; Urry, 1996). This view of generations traces the movement of generations from one to another starting from the oldest generation to the current generation Y.

In addition, Karl Mannheim (1928/1952) in his studies found that a generation has moved from a focus on people being associated with 'kin' or generations based on family relations to sociological significance where generations were based on 'kith' or cohort (people who are closely associated with certain events or born almost at the same time in history).

\section{Generational Cohort Theory}

Generational Cohort theory has advanced the argument that people who were born, grew up together and shared same events in history will embrace similar values and which are different from other generational groups (Kupperschmidt, 2000; Mannheim, 1972; Smola \& Sutton, 2002; Strauss \& Howe, 1991; Thau \& Heflin, 1997). The year of birth has been used to demarcate the cohorts as per generational studies carried out in North America. However, studies conducted in Europe show less consistency in demarcation using age due to differences in history that existed among European countries. Most studies found that generational cohorts have similar values which bind them together and influence their behaviour and motivation.

\section{Generational Differences}

The workforce in many organizations is currently made up of three generations: Baby Boomers, Generation $\mathrm{X}$ and Generation $\mathrm{Y}$. These generations came to the workplace with different expectations, needs and values which are based on their shared early social and economic experiences unique to the time each generation lived (Eisner, 2005; Howe \& Strauss, 1991; Wolburg \& Pokrywczynski, 2001; Zemke, Raines \& Filipczath, 1999). The naming of generations has been a subject of debate among researchers. Though there is a general agreement in the naming of the first two generations, some disagreements have emerged in naming of the latter. In the US, they refer Generation $\mathrm{Y}$ as the Millennials while some researcher have used the term Generation Y-ers (Jennings, 2000). This study has used the term Generation Y-ers.

Generational differences have existed throughout in history and many years. A generation was defined according to the historical period and social events which were shared by people of the 
same cohort (Lyons, Duxbury \& Higgins 2005; Mannheim, 1959). Mannheim argued that the boundaries between generations were established as a result of occurrence of some significant historical events which shaped the lives of people born during and about the same time period. (Mannheim, 1959). Mannheim further indicated that as a result of these events, people within a given cohort exhibited behaviour and attitudes which are similar and which varies with the time they grew up. (Lyons et al. 2005; Mannheim, 1959).

Ryder (1965) defines a Generational cohort as "a group of individuals similar in age who have experience same time period." His view on generation provides a good basis for the understanding of generational differences. Kowske, Rasch, \& Wiley (2010) argued that a generation constitute people who were born around the same time and bound by common events such as wars and significant technological advances. The generational cohort also experienced similar events in their lives such as going to school, working and retiring together.

As Kowske et al. (2010) pointed out, a generation is shaped by similarity of events experienced by a group of people growing up together. Different generations will encounter different events in their life time. These events have the capacity to determine their outlooks. The term "generational cohort" has now been accepted to identify and describe various generational groups of individuals born within a certain age range (Shacklock \& Brunetto, 2011). Becton, Walker, \& Jones-farmer (2015) in their studies established that a generational cohort is composed of people bound together by year of birth, age and certain events experienced in their lifetime. In addition, Colette and Stein (2014) indicated that multigenerational workforce view workplace differently in terms of what affect their retention and performance. As the workplace structure continue to change, multiple generations will be expected to work together and not operate in isolation (Jora and Khan, 2014). Further, having understanding of different generations and their specific needs is key to organizational success (Bennet, Pitt \& Price 2012). Additionally, leaders of multigenerational employees tend to treat them in a similar manner with disregard to their classification, individual characteristic and needs (Nelsey \& Brownie, 2012).

\section{Empirical Literature Review Employee Retention}

Studies by Delloite (2014) found that retaining skilled staff in a competitive environment is the biggest challenge facing human resource managers in Kenya today. A survey of Kenyan corporates by Delloitte (2014) established that $80 \%$ of managers who were surveyed indicated employee that retention was their key priority in management of human capital. Most of the companies, that is $52 \%$, admitted that they were not ready to cope with the challenge of employee retention. This shows the magnitude of retention problem in Kenya. In this war for highly skilled staff, Kenyan companies may be the ones that are losing out. The need for employee retention has further been identified by Kenyan companies as a result of poaching of employees from competing firms (Ernst \& Young, 2013).

An international study by Towers Perrin (2005) carried out among 86,000 full-time employees in 16 counties identified certain critical factors in employee retention. Such factors include: offering employees competitive pay, work-life balance opportunities and other attractive work benefits. The study also established the existence of similarities between factors responsible for attracting employees to the organization and the difference in factors responsible for their retention once 
hired by the organization. This implies that things that bring people in the organizations are not the one that keeps them. Employers should be more concerned with how to keep their top talents once brought into the organization.

Umer and Naseem (2011) in their study established that work-life balance and career development has a positive impact in retaining workers. Similarly, D'Amato and Herzfeldt (2008) undertook a study among European managers on employee intention to stay and organizational commitment of Baby Boomers and Generational X-ers. They established a higher intention to leave among Boomers followed by Generation X employees. This suggest that there exists a difference in the retention among different generations. The relatively high intention of early Baby Boomers to leave their organization suggested that retirement age influenced their responses. As employees advance in age, they exhibit a higher intention to leave. This finding suggests that for organizations to retain critical skills, they should focus more attention on factors likely to retain Generation $\mathrm{X}$ and Generation Y employees.

\section{Generational Differences and Retention}

There has been a raging debate on Generational differences and factors that influence their retention. Studies on Generational differences by Parry and Urwin (2011) identified characteristics among various generational groups that existed in the form of career stage, age, or individual differences between people and which were crucial in determining their retention. Similarly, Studies by (Smola \& Sutton 2002; Carver \& Candell 2011; Shacklock \& Bradely 2012) found the existence of generational differences in retention of employees as presented in Table 1.

Table 1: Key retention drivers

\begin{tabular}{|c|c|}
\hline Generation & Key Retention Drivers \\
\hline Generation Y & $\begin{array}{l}\text { Training and development opportunities } \\
\text { Regular promotion opportunities } \\
\text { Clearly communicated career paths } \\
\text { Clearly communicated succession planning } \\
\text { Mentor/Mentee programs } \\
\text { Work life balance and flexible work hours Good relationships with supervisors and } \\
\text { colleagues } \\
\text { The work itself }\end{array}$ \\
\hline Generation X & $\begin{array}{l}\text { Clearly communicated succession planning } \\
\text { Performance evaluation system that is linked to recognition and rewards programs } \\
\text { Work life balance and flexible work hours Good relationships with supervisors and } \\
\text { colleagues } \\
\text { Recognition of professional status } \\
\text { The work itself } \\
\text { Good pay }\end{array}$ \\
\hline
\end{tabular}




\begin{tabular}{|l|l|}
\hline Baby & Stable employment \\
Boomers & Reduced work-family-conflict \\
& Participative decision making \\
& Good relationships with colleagues and supervisors \\
& The work itself \\
Mentor/Mentee programs \\
Provision of professional opportunities \\
Good pay and conditions \\
Performance evaluation system that is linked to recognition and rewards programs \\
Autonomous work environment
\end{tabular}

\section{Baby Boomers and Retention}

Boomers generation are regarded as the largest and most popular of all the generations. This generation experienced a surge in the birth rate during the world's Great depression and world war II (Tavener, Byles \& Loxton, 2014). The composition of workforce is changing very fast due to the decision by Baby boomers to continue working beyond the retirement age (Roodin \& Mendelson, 2013). In the current workplace, Baby boomers have increased desire for promotions and top-level positions but they do experience restrictions due to lack information technology skills. Nevertheless, some managers feel the need to retain them because of the belief that their vast knowledge about the organization and professional expertise in dealing with organizational issues should be retained (Salb, (2015).

\section{Generation $X$ and Retention}

Generation X, also commonly referred to as the X-ers are between the ages of 35-53. The events that shaped members of this generational cohort were: Organizational downsizing, industrial restructuring, and increasing rates of temporary and part-time employment (Kahn and Galabos, 2014). This generation has preference for work environment that provides for flexibility at the workplace and to accommodate other life interests. Al-Asfour and Lettau (2014) postulated that this generation had more interest in technology given the fact that they were born during the technology era. They also prefer work-life balance environment as they needed time with their families. Additionally, this generational group is hard working and results oriented. They have great preference for work and can multi-task. They also derive maximum job satisfaction and engagement (Hernaus \& Vokic, 2014). Generation X faced a tougher economy than the Baby Boomers and lived in more dual career families. As a result of having both parents working, they developed a sense of individual initiative and independence (Howe \& Strauss, 2000; Kupperschmidt, 1998; Lancaster \& Stillman, 2002). They not only consider work to be important to them but also appreciate flexible schedules, informal work environments and the less excessive supervision (Zemke et al., 2000). In addition, they have advanced technological skills and prefer team oriented as well as working independently. They consider work-life balance and good work relationships dear to them than the Boomers generation (Chao, 2005). 


\section{Generation Y and Employee Retention}

Generation $\mathrm{Y}$ is the youngest generation currently in the workforce. This generation is also referred to as the millennial or generation Y-ers. They have more preference for leisure and freedom. They prefer working in a flexible environment as work is less central to their lives (Twenge, 2010). They are considered to be the most technology savvy among all the generations. This is because they were born and spent their lives during the digital era (Bolton, Parasuraman, Hoefnaggels, Mighes \& Kabadayi, 2013). The Millennials acquired their technical knowhow from their exposure to internet technology and ability to network widely. In addition, they have preference to work in a challenging work environment compared to other generations (Akkucuk, 2016). Over 90\% of generation $\mathrm{Y}$ is extensively involved in computer networks. They are also receptive to new ideas and challenges (Young \& Hinsley 2012). Studies by Murray (2015) found that this generation is driven by high desire for achievement. They are goal oriented, innovative and prefer meaningful and value addition jobs. Members of this generation prefer working for transparent and progressive organizations that meet their expectations (Ferri-Reed, 2014). This generational cohort have unique work values that distinguishes them from other organizations. In addition, they have preference for learning and development of their skills (winter and Jackson, 2016).

In addition, studies by Rosenwitz and Iyor (2009) established that generation Y have preference for workplace flexibility when undertaking jobs. This generation when asked to make a choice between personal life and work, they choose family and friends (Shaw \& Fairhast, 2008). The preference for work-life balance is increasing among this generation with adoption of high speed internet technology in homes thereby making it possible for them to work away from home (Prokopeak, 2013). Generation Y employees are people who embrace flexibility and would prefer to telecommute as they work from homes so as to be with their family.

\section{Methodology}

\section{Research Design}

This study used both cross-sectional and descriptive survey research design to derive data from two or more sources while allowing collaborative patterns of convergence to develop data for good interpretation. Cross sectional studies have been found to be robust in relationships studies. They capture the population characteristics as they freely and naturally occur (O'Sulliva \& Abel, 2007). The design is appropriate because it captured data that can be used to provide both qualitative and quantitative measurement cues on the variables under study in a manner that is objective and efficient (Cooper \& Schindler, 2008).

\section{Study Population}

The study population consisted of all the 314 firms operating in the telecommunications sector in Kenya. For purposes of market segmentation and licensing, the firms are divided in three categories, namely Network Facilities Providers (NFP), Application Service Providers (ASP) and Content Service Providers (CSP). From this study population, a representative sample of 131 was surveyed.

\section{Data Collection Procedure}

A permit to conduct research was obtained and presented to the chief executives of the telecommunication firms who then authorized the human resource department in the firms to 
facilitate the study. Questionnaires were then distributed to the engineers and picked later. We called to follow up on the responses. Questionnaires were appropriate because they could be filled independently by the respondents and is suitable for a large survey study involving a large number of respondents.

\section{Reliability and Reliability}

The questionnaire was tested for validity and reliability using data collected from 17 engineers from the target population ( $10 \%$ of the targeted population) but who were excluded from the actual survey, in order to help the researcher detect weaknesses in the data collection tool, design and instrumentation such as ambiguous and unclear questions (Cooper \& Schindler, 2008).

Reliability and validity of the item measures used in the questionnaire were assessed for internal consistency using Cronbach's alpha statistic. This is a test of the consistency of the respondent's answers to all the items in the questionnaire. Results showed that all the constructs had Cronbach's alpha value of at least 0.70 which was considered acceptable (Drost, 2011).

A summary of the results showing the Cronbach's alpha of the items tested is given in Table 2

Table 2: Table showing reliability Statistics

\begin{tabular}{|l|l|l|l|}
\hline Construct & Cronbach's Alpha & N of Items & Mean \\
\hline Employee engagement & 0.885 & 10 & 3.40 \\
\hline Job satisfaction & 0.896 & 9 & 3.40 \\
\hline Affective commitment & 0.757 & 3 & 3.60 \\
\hline Continuance Commitment & 0.736 & 5 & 3.39 \\
\hline Normative commitment & 0.736 & 7 & 2.43 \\
\hline
\end{tabular}

In addition, the results of EFA revealed that Kaiser-Mayer-Olkin (KMO) statistics which is a measure of sampling adequacy was higher than the minimum recommended value of 0.60 (Kaiser, 1974) for most of the constructs.

Table 3: KMO and Bartlett's Test for sample adequacy

\begin{tabular}{|l|l|l|}
\hline Kaiser-Meyer-Olkin Measure of Sampling Adequacy. & 0.550 \\
\hline Bartlett's Test of Sphericity & Approx. Chi-Square & 5734.071 \\
\cline { 2 - 3 } & Df & 276 \\
\cline { 2 - 3 } & Sig. & 0.000 \\
\hline
\end{tabular}

The sample for retention was adequate for the analysis as shown significant at p-value less than 0.001 .

Validity of the instrument was also tested in the pilot study. An instrument is considered valid when it has the capacity to measure what it is intended to measure. Content validity pertains to the degree to which the instrument fully assesses or measures the construct of interest (Allen \& Yen, 1979). Face validity is a component of content validity and is established when an individual reviewing the instrument concludes that it measures the characteristic or trait of interest. The respondents were asked to comment on the questions wording, sequence and layout so as to 
establish 'face validity' criterion. In regard to this, few corrections were suggested for some of the questions by the respondents.

\section{Functional Specifications of the Study}

The functional specifications that were used to examine the relationships between the constructs, namely Generational differences (GD) and employee retention (ER) are as follows:

$\mathrm{ER}=\mathrm{f}\left(\mathrm{G}_{\mathrm{B}}, \mathrm{G}_{\mathrm{x}}, \mathrm{G}_{\mathrm{y}}, \varepsilon_{\mathrm{i}}\right)$

Where $\mathrm{G}_{\mathrm{b}}, \mathrm{G}_{\mathrm{x}}$, and $\mathrm{G}_{\mathrm{y}}$ represent Boomers, $\mathrm{X}$-ers and $\mathrm{Y}$ 's generation and $\varepsilon^{\mathrm{i}}$, $\varepsilon_{\mathrm{j}}$ and $\varepsilon_{\mathrm{k}}$ are error terms associated with the specified functions. It should be noted employee engagement (EE), organizational commitment (OC) comprising three sub-constructs, namely affective commitment (AC), normative commitment (NM), continuance commitment (CC) and job satisfaction were used as proxies for employee retention.

\section{Operational Measures of Study Variables}

The independent variables of the study the generational differences (Baby boomers: 1946-1964, Generation X: 1965 -1979, Generation Y: 1979 to 2000), employer branding (visual corporate identity and brand image) and work-life balance. The dependent variable of the study is employee retention (ER) whose measures were employee engagement (EE), organizational commitment OC) and job satisfaction (JS) satisfaction.

Table 4: Summary of the Operationalization of the study variables

\begin{tabular}{|c|c|c|}
\hline Variable & $\begin{array}{l}\text { Indicator } \\
\text { Measurement }\end{array}$ & Scale \\
\hline $\begin{array}{l}\text { Generational differences } \\
\text { (Independent variables } \mathbf{G}_{\mathbf{B}} \text {, } \\
\mathbf{G}_{\mathbf{x}}, \mathbf{G}_{\mathbf{y}} \text { ) }\end{array}$ & $\begin{array}{ll}\text { Age bracket/range } & \\
\text { Baby boomers: } & 1946-1964 \\
\text { Generation X: } & 1965-1979 \\
\text { Generation Y: } & 1980-2000\end{array}$ & $\begin{array}{l}\text { Five Point Likert - } \\
\text { Type Scale }\end{array}$ \\
\hline $\begin{array}{l}\text { Employee retention } \\
\text { Dependent } \\
\text { Variable Y }\end{array}$ & $\begin{array}{l}\text {-Employee engagement } \\
\text { Employee satisfaction } \\
\text { Professional growth opportunities } \\
\text { Job security } \\
\text { Recognition of performance } \\
\text { Good cooperation with other work } \\
\text { groups } \\
\text { Attraction to the organization by pay } \\
\text { and benefits } \\
\text { Being valued by the employer } \\
\text {-Organizational commitment } \\
\text { Emotional attachment to the } \\
\text { organization } \\
\text { Strong sense of belonging to the } \\
\text { organization } \\
\text { Continue working for the organization } \\
\text { Intend to stay in the organization. }\end{array}$ & $\begin{array}{l}\text { Five Point Likert - } \\
\text { Type Scale }\end{array}$ \\
\hline
\end{tabular}



Readiness to leave theory
Loyalty to employer
Cost of leaving job
Job Satisfaction
Satisfaction with the job
Challenging and stimulating job
Opportunity to learn new things
Fun working environment
Opportunity to exercise creativity
Dissatisfaction with the job.
Opportunity for personal growth
Job offers a sense of personal
accomplishment
Attractiveness compensation

Table 5: Research Objectives, Hypothesis and Data Analysis Methods

\begin{tabular}{|c|c|c|}
\hline Objective(s) & Hypotheses & Data Analysis Methods \\
\hline $\begin{array}{l}\text { 1.To establish the relationship } \\
\text { between generational } \\
\text { differences and employee' } \\
\text { retention in telecommunications } \\
\text { firms in Kenya. }\end{array}$ & $\begin{array}{l}\mathrm{H}_{1} \text { : There is no relationship } \\
\text { between generational differences } \\
\text { and employee' retention in } \\
\text { telecommunications firms in } \\
\text { Kenya. }\end{array}$ & $\begin{array}{l}\text { Employee retention = f } \\
(\mathrm{Gy}, \mathrm{Gx}, \mathrm{Gb} . . \varepsilon), \\
\text { ANOVA and Linear } \\
\text { regression with dummy } \\
\text { variable. }\end{array}$ \\
\hline
\end{tabular}

\section{Data Analysis Methods}

Upon completion and collection of the filled questionnaires, they were checked for completion and incomplete ones discarded. The data was then codded and entered into the computer and analyzed using SPSS version 22. The analysis proceeded in three steps. First the characteristics of the respondents were examined by generating frequency distributions. This was followed by descriptive statistics on the study variables namely work-life balance, employer branding and employee retention. Third, correlation analysis was used to study the relationship between pairs of variables. Further, the influence of employer branding and work-life balance was studied using regression analysis while the variation of employer branding, work-life balance and employee retention was examined using analysis of variance (ANOVA model). The ANOVA done to determine whether the retention of engineers is similar between male and female engineers.

\section{Results and Discussion}

In this study we first established the results of descriptive analysis. The following tables presents the means, standard deviations and correlation analysis of the study variables:

\section{Response Rate}

The targeted respondents in this study were engineers from telecommunications companies in Kenya. A total of 131 engineers responded to the study compared to a target of 173 respondents. This represented a response rate of $76 \%$. Based on Saunders, et al (2003) assertion, the response rate for this study can be rated as very good at $76 \%$ for the engineers. This high response rate was attributed to the data collection procedures which involved drop and pick method. The researcher 
administered questionnaires to the respondents who completed them at their convenient time and picked afterwards. This was also complemented by follow up calls to the respondents to whom the questionnaires had been distributed.

Distribution respondents according to generational cohorts. The respondents were categorized into different generational cohorts according to their age brackets as shown in Table 6.

Table 6: Generational cohorts of respondents

\begin{tabular}{|l|l|l|}
\hline Generational cohorts & Frequency & Percentage \\
\hline Boomers (1947-1964) & 14 & 10.7 \\
\hline Generation X (1965-1979) & 21 & 16.0 \\
\hline Generation Y (1980-2000) & 96 & 73.3 \\
Total & 131 & 100 \\
\hline
\end{tabular}

Source: Research Data (2018)

Table 6 shows that more than $73 \%$ of the respondents were Generation Y in the age bracket (19802000). Boomers (1947-1964) are the least in number at 10\%. Engineers in this generation are approaching retirement. Generation X (1965-1979) were 16\% of the respondents. Majority of respondents were young engineers who are more technology savvy.

Distribution by educational level of respondents. The respondents were asked to indicate their highest level of education and the research findings are presented in Table 7.

Table 7: Educational level of respondents

\begin{tabular}{|l|l|l|}
\hline Education & Frequency & Percentage \\
\hline Diploma & 11 & 8.4 \\
\hline Bachelor degree & 92 & 70.2 \\
\hline Technical profession certificate & 14 & 10.7 \\
\hline Masters & 14 & 10.7 \\
Total & 131 & 100 \\
\hline
\end{tabular}

Source: Research data (2018)

Table 7 shows that majority of respondents $70.2 \%$ have Bachelor degree, $8.8 \%$ have Diploma qualification, $10.7 \%$ are Technical professional certificate holders and $10.7 \%$ have Masters degree. This data indicates that a large percentage of Engineers in the Telecommunications sector are Bachelor degree graduates. There are few Engineers holding Masters degree.

\section{Organizational Profile}

The organizational profile gives the characteristics of the firms in the Telecommunications sector in Kenya used in the study. The respondents were asked to indicate the name of their organizations and the specific category of their organization within the Telecommunications sector in Kenya. Below in Table 8 are the findings.

Table 8: Category of organizations in the telecommunications sector

\begin{tabular}{|l|l|l|}
\hline Type of Service provider & Frequency & Percentage \\
\hline Network service providers (NSP) & 78 & 59.6 \\
\hline
\end{tabular}




\begin{tabular}{|l|l|l|}
\hline Application service providers (ASP) & 32 & 24.4 \\
\hline Content Service Providers (CSP) & 20 & 16.0 \\
Total & 131 & 100 \\
\hline
\end{tabular}

Source: Research Data (2018)

The results in Table 8 show that there were 78 Engineers from Network Facility Provider (NFP) firms representing $60 \%$. This is because in this category, the key companies operating in the telecommunications sector such as Safaricom, Airtel Kenya and Telecom Kenya are the leading employers of Engineers in the Telecommunications sector. There were 32 respondents in the Applications Service Provider (ASP) representing $24 \%$. Respondents from Content Service Provider (CSP) were $16 \%$ of engineers.

\section{Normality of Data on Employee Retention}

Normality test was done using Skewness and kurtosis to determine whether the data on employee retention was normal. Employee retention was measured using job satisfaction, employer branding and organizational commitment as proxies. The higher the rating of these proxies, the higher was the probability of retention. These results are shown in Table 9

Table 9: Normality test on employee retention

\begin{tabular}{|c|c|c|c|c|c|c|}
\hline $\begin{array}{l}\text { Generation } \\
\text { cohort }\end{array}$ & & $\begin{array}{l}\text { Employee } \\
\text { engagement }\end{array}$ & $\begin{array}{l}\text { Job } \\
\text { satisfaction }\end{array}$ & $\begin{array}{l}\text { Affective } \\
\text { commitment }\end{array}$ & $\begin{array}{l}\text { Continuance } \\
\text { commitment }\end{array}$ & $\begin{array}{l}\text { Normative } \\
\text { commitment }\end{array}$ \\
\hline \multirow[t]{5}{*}{ Boomers } & Mean & 2.648 & 3.595 & 3.488 & 3.438 & 2.705 \\
\hline & $\mathrm{N}$ & 14 & 14 & 14 & 14 & 14 \\
\hline & Std. Deviation & 0.1084 & 0.2564 & 0.0791 & 0.1883 & 0.4375 \\
\hline & Kurtosis & 9.894 & 3.904 & 2.923 & 3.428 & -0.317 \\
\hline & Skewness & 3.029 & -1.781 & -0.308 & -2.127 & -1.097 \\
\hline \multirow[t]{5}{*}{ Generation $\mathrm{X}$} & Mean & 4.071 & 4.069 & 3.897 & 4.018 & 2.726 \\
\hline & $\mathrm{N}$ & 21 & 21 & 21 & 21 & 21 \\
\hline & Std. Deviation & 0.3901 & 0.5182 & 0.5785 & 0.3629 & 0.3804 \\
\hline & Kurtosis & -0.962 & 0.465 & -0.846 & -0.642 & -1.661 \\
\hline & Skewness & 1.02 & 0.385 & 0.906 & 1.049 & 0.259 \\
\hline \multirow[t]{5}{*}{ Generation Y } & Mean & 3.352 & 3.715 & 3.573 & 3.464 & 2.449 \\
\hline & $\mathrm{N}$ & 96 & 96 & 96 & 96 & 96 \\
\hline & Std. Deviation & 0.5787 & 0.5429 & 0.3943 & 0.3902 & 0.4672 \\
\hline & Kurtosis & 0.027 & -0.201 & -0.568 & -0.809 & -1.054 \\
\hline & Skewness & 1.012 & 0.573 & 0.518 & -0.488 & -0.504 \\
\hline \multirow[t]{5}{*}{ Total } & Mean & 3.392 & 3.759 & 3.616 & 3.55 & 2.521 \\
\hline & $\mathrm{N}$ & 131 & 131 & 131 & 131 & 131 \\
\hline & Std. Deviation & 0.6362 & 0.532 & 0.4261 & 0.4211 & 0.4639 \\
\hline & Kurtosis & -0.608 & 0.009 & 0.938 & 0.363 & -0.796 \\
\hline & Skewness & 0.674 & 0.55 & 1.037 & -0.007 & -0.518 \\
\hline
\end{tabular}

From table 9, the means for employee retention were: employee engagement $(\mathrm{M}=3.392$, $\mathrm{SD}=0.6362)$, job satisfaction $(\mathrm{M}=3.759,0.532)$, affective commitment $(\mathrm{M}=3.616, \mathrm{SD}=0.4261)$, normative commitment $(\mathrm{M}=2.521, \mathrm{SD}=0.4639)$ and continuance commitment $(\mathrm{M}=3.55$, $\mathrm{SD}=0.4211$ ). The overall means for retention are 3.46 , with a standard deviation, $\mathrm{SD}=0.4518$ 
The results shows that there is moderate retention of employees across all generations within the telecommunication sector in Kenya and that all the generational cohorts have very low normative commitment to their firms with generation Y having the least normative commitment. It should be noted that employee engagement (EE), job satisfaction (JS) and organizational commitment comprising affective commitment (AC), continuance commitment (cc) and normative commitment (NC) were used as proxies for employee retention. In this respect, a high rating on these variables would imply high levels of retention and vice versa.

\section{Hypothesis Testing}

The aim of this part is to test the hypotheses used in the study. These variables include generational differences and Engineers retention. To test the hypotheses, Analysis of Variance (ANOVA), independent t-test and linear regression with dummy variables were used.

\section{Relationship Between Generational Differences and Employee Retention}

In this study, objective one was to establish the relationship between generational differences and employee retention. The corresponding hypothesis is as follows:

$\mathrm{H}_{01}$ : There is no significant difference in employee retention across generations in telecommunications firms in Kenya.

This hypothesis was tested using ANOVA and the results presented in Table 14.

Table 14: ANOVA for Generational differences and employee retention

\begin{tabular}{|l|l|l|l|l|l|}
\hline Engineers retention & Sum Squares & d.f. & Mean Square & F & P-value \\
\hline Between Groups & 2.858 & 2 & 1.429 & 12.311 & .000 \\
\hline Within Groups & 14.856 & 128 & .116 & & \\
\hline Total & 17.713 & 130 & & & \\
\hline
\end{tabular}

The results in table 14 shows there was a significant difference (p-value $0.000<0.05$ ) in mean scores of responses among various generational groups with regard to retention. In order to ascertain differences among generational cohorts with regard to employee retention, an independent t-test was undertaken as given in table 15

Table 15: Independent t-tests for Generational differences and employee retention

\begin{tabular}{|l|l|l|l|l|l|}
\hline Case & Generational cohort & Mean & Std. & Se & p value \\
\hline \multirow{2}{*}{1} & Boomers (1946-1964) & .8227 & .12623 & .03374 & $<0.001$ \\
\cline { 2 - 5 } & X-ers (1965 - 1979) & 1.3851 & .31455 & .06864 & \\
\hline \multirow{2}{*}{2} & Boomers (1946-1964) & .8227 & .12623 & .03374 & \multirow{2}{*}{$<0.001$} \\
\cline { 2 - 5 } & Y-ers (1980 - 2000) & 1.0718 & .36519 & .03727 & \\
\hline \multirow{2}{*}{3} & X-ers (1965 - 1979) & 1.3851 & .31455 & .06864 & $<0.001$ \\
\cline { 2 - 5 } & Y's (1980 - 2000) & 1.0718 & .36519 & .03727 & \\
\hline
\end{tabular}

From table 15 the study found a significant (p-value $0.001<0.05$ ) difference in retention of engineers between the two generational cohorts (Boomers (1946 - 1964) and X-ers (1965 - 1979)). The results imply that there is a significant difference in employee retention across the three 
generation cohorts. Further, the p-value $0.013<0.05$ for the two generational cohorts (Boomers (1946 - 1964) and Y-ers (1980 - 2000)) indicate that there is a significant difference in their retention. Similarly a p- value $<0.001<0.05$ shows that the two cohorts (X-ers $(1965-1979)$ and Y-ers $(1980$ - 2000)) are significantly different with regard to retention rates Thus all the generational cohorts had significant differences ( $p$-value $0.001<0.05)$ in their retention at the telecommunication firms in Kenya.

Further, the individual statistical significance was tested using t test and by use of linear regression with dummy variables to test the relationship between generational differences and employee retention across the three generations as given in Table 16

Table 16: Dummy variable regression of Generational differences on employee retention - xi:regress er_i.generati

i.generati _Igenerati_1-3 (naturally coded; _Igenerati_1 omitted)

\begin{tabular}{|c|c|c|c|c|c|c|}
\hline Source & SS & df & MS & Number of obs & $=$ & 131 \\
\hline Model & 2.85764685 & 2 & 1.42882342 & Prob $>F$ & $=$ & 0.0000 \\
\hline Residual & 14.8556732 & 128 & .116059947 & R-squared & $=$ & 0.1613 \\
\hline Total & 17.7133201 & 130 & .136256308 & Root MSE & $=$ & .34068 \\
\hline
\end{tabular}

\begin{tabular}{r|rrrrrr}
\hline er_ & Coef. & Std. Err. & $\mathrm{t}$ & $\mathrm{p}>|\mathrm{t}|$ & [95\% Conf. Interval] \\
\hline Igenerati_2 & .5624434 & .1175443 & 4.78 & 0.000 & .3298619 & .7950248 \\
_Igenerati_3 & .2490804 & .0974626 & 2.56 & 0.012 & .056234 & .4419267 \\
_cons & .8226956 & .0910494 & 9.04 & 0.000 & .6425388 & 1.002852 \\
\hline
\end{tabular}

Table 16 shows the results of dummy variable regression for generational differences and employee retention. The results shows that there are very significant differences $(\mathrm{p}<0.001)$ between generations cohorts with regard to employee retention.

Using regression coefficients, the estimated equation is as follows:

\begin{tabular}{|c|c|c|c|}
\hline & (士0.091) & (士0.118) & $( \pm 0.097)$ \\
\hline & (O.OOO) & $(0.000)$ & \\
\hline
\end{tabular}

The difference in employee retention is more significant between boomers and $\mathrm{X}$-ers $(\mathrm{p}<0.001)$ than between boomers and Y-ers $(\mathrm{p}<0.5)$. The highest retention is for generation $y$ followed by generation $\mathrm{X}$ while the lowest is boomers. Further, the results show that there is significant differences ( $\mathrm{p}$ value $0.001<0.05$ ) in employee retention between generation $\mathrm{X}$ and the generation $\mathrm{Y}$. This finding shows that retention of generation $\mathrm{X}$ and generation $\mathrm{Y}$ are different. This finding is supported by previous studies by Parry and Urwin (2011) who found that generational differences in personal characteristics influence employees' intention to stay. Similarly, studies by 
(Smola \& Sutton 2002, Carver \& Candell, Shacklock \& Bradely, 2012) established that there are differences in retention of employees depending on the generational differences. The lowest retention of boomers could be explained by the fact that these are the least represented and also the cohort that is proceeding on retirement.

\section{Mean of Retention Among Employees Across Generations}

Figure 1 shows that there is significant difference in retention between Boomer, X-ers and Y's generation.

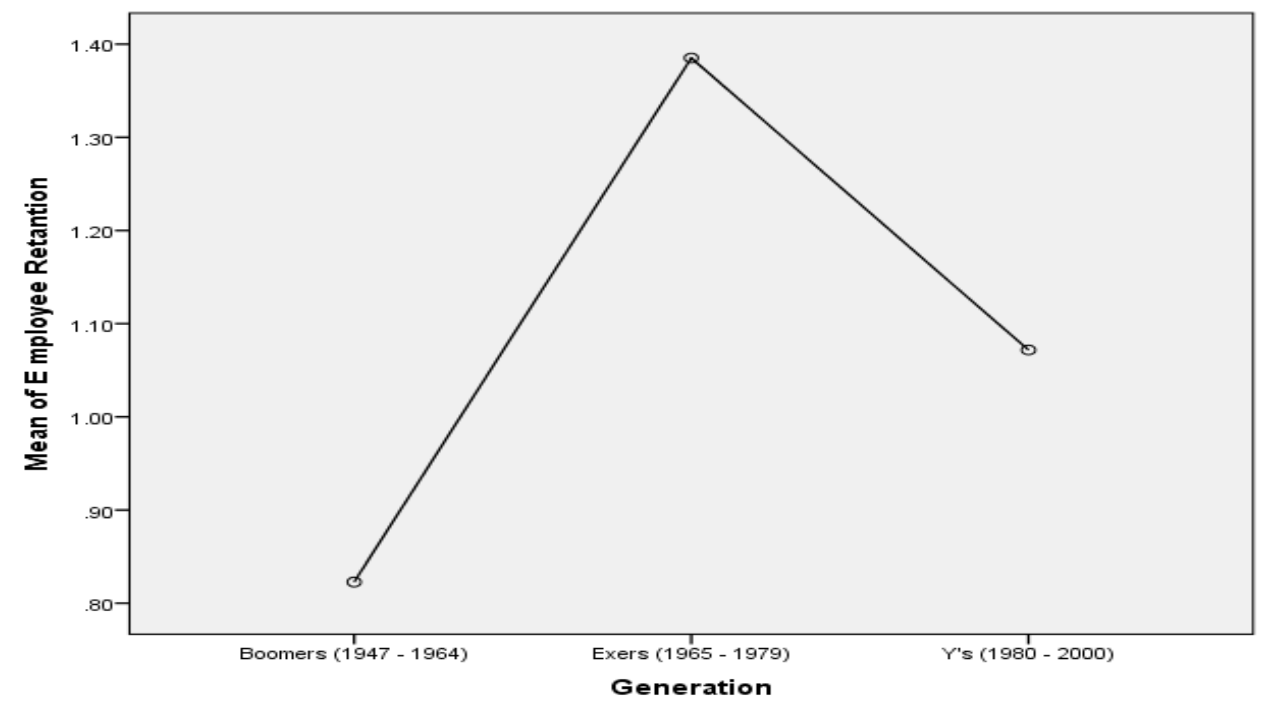

Figure 1: Mean of employee retention across generations

Figure 1 shows that there is significant difference in retention between Boomer, X-ers and Y's generation. The overall mean score for Boomers (1946 - 1964) was 0.8227 with standard deviation of 0.12623 , Generation X (1965 - 1979) had a mean of 1.3851 with standard deviation of 0.31455 and Generation Y (1980 - 2000) had a mean of 1.0718 with standard deviation of 0.36519 .

Since the response variable had three levels (boomers, X-ers and Y-ers) multi-nominal logistic regression was used to determine the relationship between generational differences and employee retention. The results is presented as follows:

Table 17: Relationship between generational differences and employee retention.

\begin{tabular}{|c|c|c|c|c|c|c|c|c|}
\hline \multicolumn{9}{|c|}{ Parameter Estimates } \\
\hline \multirow[t]{2}{*}{ Generation $^{\mathbf{a}}$} & \multirow[t]{2}{*}{ B } & \multirow[t]{2}{*}{$\begin{array}{l}\text { Std. } \\
\text { Error }\end{array}$} & \multirow[t]{2}{*}{ Wald } & \multirow[t]{2}{*}{ Df } & \multirow[t]{2}{*}{ Sig. } & \multirow[t]{2}{*}{$\begin{array}{c}\text { Odd Ratio } \\
\text { (OR) }\end{array}$} & \multicolumn{2}{|c|}{$\begin{array}{c}95 \% \text { Confidence } \\
\text { Interval for } \operatorname{Exp}(B)\end{array}$} \\
\hline & & & & & & & $\begin{array}{l}\text { Lower } \\
\text { Bound }\end{array}$ & \begin{tabular}{|l|} 
Upper \\
Bound
\end{tabular} \\
\hline Boomers (1947 Intercept & .539 & .986 & .300 & 1 & .584 & & & \\
\hline \begin{tabular}{|l|l}
$-1964)$ & ER \\
\end{tabular} & -2.637 & 1.112 & 5.623 & 1 & .018 & 0.072 & .008 & .633 \\
\hline Exers (1965 - & -4.646 & 1.038 & 20.018 & 1 & .000 & & & \\
\hline \begin{tabular}{|l|l}
$1979)$ & ER \\
\end{tabular} & 2.539 & .760 & 11.151 & 1 & .001 & 12.672 & 2.855 & 56.253 \\
\hline
\end{tabular}


There was a significant difference in retention of employees between Y-ers and Boomers $(\mathrm{p}<0.18<0.05)$ and between $\mathrm{Y}$-ers and $\mathrm{X}$-ers $(\mathrm{p}<0.001)$. The generation to which an employee belonged significantly influenced their retention.

\section{Generational Difference, Employee Engagement, Job Satisfaction, And Organizational} Commitment

An analysis of variance on means of employee engagement (EE), job satisfaction (JS and organizational commitment OC (affective commitment (AC), Continuance commitment (CC) and normative commitment (NC) across the generational cohorts was done and the results are presented in Table 18.

Table 18. ANOVA of employee retention by generational cohorts (differences)

\begin{tabular}{|c|c|c|c|c|c|c|c|}
\hline & & & $\begin{array}{l}\text { Sum of } \\
\text { Squares }\end{array}$ & df & $\begin{array}{c}\text { Mean } \\
\text { Square }\end{array}$ & $\mathbf{F}$ & Sig. \\
\hline \multirow{3}{*}{$\begin{array}{l}\mathrm{EE}_{-} \\
{ }^{-} \\
\text {GEN }\end{array}$} & $\begin{array}{l}\text { Between } \\
\text { Groups }\end{array}$ & (Combined) & 17.604 & 2 & 8.802 & 32.177 & $<0.001$ \\
\hline & $\begin{array}{l}\text { Within } \\
\text { Groups }\end{array}$ & & 35.015 & 128 & 0.274 & & \\
\hline & Total & & 52.62 & 130 & & & \\
\hline \multirow[t]{3}{*}{$\begin{array}{l}\mathrm{JS}_{-}{ }^{*} \\
\mathrm{GEN}\end{array}$} & $\begin{array}{l}\text { Between } \\
\text { Groups }\end{array}$ & (Combined) & 2.574 & 2 & 1.287 & 4.815 & 0.01 \\
\hline & $\begin{array}{l}\text { Within } \\
\text { Groups }\end{array}$ & & 34.22 & 128 & 0.267 & & \\
\hline & Total & & 36.794 & 130 & & & \\
\hline \multirow[t]{3}{*}{$\begin{array}{l}\mathrm{AC}_{-} \\
* \\
\text { GEN }\end{array}$} & $\begin{array}{l}\text { Between } \\
\text { Groups }\end{array}$ & (Combined) & 2.063 & 2 & 1.032 & 6.13 & 0.003 \\
\hline & $\begin{array}{l}\text { Within } \\
\text { Groups }\end{array}$ & & 21.542 & 128 & 0.168 & & \\
\hline & Total & & 23.605 & 130 & & & \\
\hline \multirow[t]{3}{*}{$\begin{array}{l}\mathrm{CC}_{-} \\
* \\
\text { GEN }\end{array}$} & $\begin{array}{l}\text { Between } \\
\text { Groups }\end{array}$ & (Combined) & 5.491 & 2 & 2.746 & 20.013 & $<0.001$ \\
\hline & $\begin{array}{l}\text { Within } \\
\text { Groups }\end{array}$ & & 17.561 & 128 & 0.137 & & \\
\hline & Total & & 23.052 & 130 & & & \\
\hline \multirow[t]{3}{*}{$\begin{array}{l}\mathrm{NC}_{-} \\
* \\
\text { GEN }\end{array}$} & $\begin{array}{l}\text { Between } \\
\text { Groups }\end{array}$ & (Combined) & 1.855 & 2 & 0.927 & 4.544 & 0.012 \\
\hline & $\begin{array}{l}\text { Within } \\
\text { Groups }\end{array}$ & & 26.119 & 128 & 0.204 & & \\
\hline & Total & & 27.974 & 130 & & & \\
\hline
\end{tabular}

From the results in table 18 , there is significant $(\mathrm{p}<0.05)$ variation in employee retention across all the generational cohorts with the greatest variation on employee engagement $\left(F_{2,128}=32.177\right.$, 
$\mathrm{p}<0.001)$, followed by continuance commitment $\left(\mathrm{F}_{2,128}=20.013, \mathrm{p}=0.001\right)$, then affective commitment $\left(\mathrm{F}_{2,128}=6.13, \mathrm{p}<0.003\right)$, job satisfaction $\left(\mathrm{F}_{2,128}=4.815, \mathrm{p}<0.01\right)$, and lastly normative commitment $\left(\mathrm{F}_{2}, 128=4.544, \mathrm{p}<0.012\right)$. To measure employee retention, employee engagement, job satisfaction and organizational commitment were used. The sub constructs of organizational commitment were: affective commitment, continuance commitment and normative commitment. The findings shows that there is a positive significant relationship between generational differences and employee retention among various generational cohorts in telecommunications firms in Kenya. However, employee engagement was found to be more positively related to employee retention followed by continuous commitment. Normative commitment had the least impact on retention. Hence, telecommunications firms in Kenya should focus more attention on efforts to increase the level of their employee engagement.

\section{Conclusions and Recommendations}

To determine the relationship between generational differences and employee retention, the study established that employee retention varies significantly across the three generations. ANOVA for generational differences between and within generational groups established that there was a statistically significant differences in retention among the three generations based on the mean scores of responses among various generational groups. In addition, ANOVA for employee retention found variation in employee retention across all generations with the greatest variation in employee engagement and least normative commitment further, the results of analysis of dummy variable regression of generational differences on employee retention found that there are very significant differences between generational cohorts with regard to employee retention. This conclusion is supported by the previous research findings that generational differences exist among employees with regard to employee retention. Previous studies found that different generational cohorts exhibit a different characteristic which contributes to differences in their retention. It can therefore be concluded that to retain Engineers in telecommunications firms organizations should provide different retention measures taking into consideration differences among generational cohorts. This is a significant contribution the study has made to the existing body of knowledge. On management implications, this study should help organization's managers, especially human resources managers to put in place suitable measures to retain various generational cohorts in the workplace. Given the scarcity of skills and talents, employee retention is key in achieving competitive advantage by organizations.

Given this research has been carried out in the telecommunications sector in Kenya, additional empirical research is needed to identify the relationship between generational differences and employee retention in different sectors of the Kenyan economy. In addition, there is paucity of literature on generational differences and retention in Kenya hence more studies are required in this area to understand the characteristics, work values and motives of different generational cohorts currently found in the workplace. Of greater interest for further studies is Generation Y or Millennial generation as they have started replacing in large numbers Boomers and X-ers generation and as they also pose greater challenge to modern human resource managers who are ill prepared to retain them. 


\section{References}

[1] Al-Asfour, A., \& Lettau, L. (2014) Strategies for leadership style for multigenerational workforce. Journal of leadership, Accountability and Ethics, 11, 58-69.

[2] Allen, M. J. \& Yen, W.M. (1979) Introduction to Measurement theory, CA: Brooks/Cole.

[3] Akkucuk, U. \& Turan C. (2016) Mobile use and online preference of millennials: A study in Yolova. Journal of international Banking and commerce 21, 1-1

[4] Becton, J. B., Walker, J. W., \& Jones- Farmer, A. (2015). Generational differences in workplace behavior. Journal of Applied Psychology, 44, 175-189.

[5] Bell, A. (2013) Five generations in the Nursing workforce. Journal for Nurses in Professional Development 29: 205-210

[6] Bennet,J., Pitt, M., \& Price, S. (2012). Understanding the impact of generational issues in the workplace Facilities 30: 278-288

[7] Bolton, R et al. (2013). Understanding Generation $Y$ and their use of social media: A review and research agenda. Journal of Service Management, 24, 245-267

[8] Chao, L. (2005). "For Gen Xers, It's Work to Live; Allowing Employees to Strike Balance Between Job and Life Can Lead to Better Retention Rates" The Wall Street

[9] Capelli, P. (2000). A market-driven approach to retaining talent. Harvard Business Review, 78(1), 103-11. Communications Authority of Kenya publication, (2016)

[10] Chartered Institute of Personnel and Development (2010) Factsheet, Employee turnover and retention. HR Practices [Internet] Revised July 2010, Available from: http://www.cipd.co.uk/subjects/hrpract/turnover/empturnretent?

[11] Colette, T. Stein, L. (2014) Stories of Generational leadership: Women higher education administrator's voices. Advancing women I leadership 34: 1-10

[12] Cooper, D.R. and Schindler, P.S. (2003) Business Research Methods. Tata McGraw Hill Publishers, Nee Dehli

[13] Cooper, D.R, \& Schindler, P. (2008). Business research methods (10th ed.). New York, McGrawHill/Irwin. Journal of Multivariate Analysis, 92, 174-185

[14] Davenport, R. (2006) 'Eliminate the skills Gap', Training+ Development Magazine, P.32

[15] Deloitte, (2014). Global human resource and talent management survey

[16] Drost, E.A. (2011) Validity and Reliability in Social Science Research. Education Research and perspectives, $38,108-123$.

[17] Eisner, S.P. (2005) Managing generation Y. Advanced Management Journal, 70, 4-15

[18] Economic survey (2016) Kenya National Bureau of Statistics, Government Printer, Nairobi.

[19] Ernest \& Young (2013) A survey on talent retention in Kenya, Nation Paper, and Nairobi

[20] Ferri- Reed, J. (2013) Leading a multigenerational workforce. The journal for quality and participation 35, 12-14

[21] Guest, D. (2011) Human Resource Management and Performance: Still searching for some answers, 21, (3-13)

[22] Greenblatt, E. (2002) Work-life balance: Wisdom or Whining, Organizational dynamics, 31, (177193)

[23] Gurumani, V.S. (2010) Invaluable tools for Talent Retention, Human capital, 45-55

[24] Hasna, A.M., \& Clark, R. (2009). The future of engineering; how to attract young people, www.sefi.be/wp-content/abstract,2009/Hasna.

[25] Hernaus, T., \& Vokic, N. (2014). Work design for different generational cohorts. Journal of organizational change Management.

[26] Howe, N., \& Strauss, W. (1991). Generations: The History of America's Future, 1584 to 2069. New York: William Morrow \& Company Inc.

[27] Jora, R., \& Khan, S. (2014). Motivating multigenerational human resource. International Journal of organizational Behaviour and Management perspectives 3, 1276-1281 
[28] Krahn,H. \& Galabos,N.(2014) Workforce values and beliefs of Generation X and Generation Y, Journal of Youth studies 17: (92-112)

[29] Kowske, B., Rasch, R., \& Wiley, J. (2010) Millennials (Lack of) attitude problem: an empirical examination of generational effects on work attitudes, Journal of Business and Psychology; 25(2), 265-279

[30] Kupperschmidt, B. R. (2000). Multigenerational employees: strategies for effective management. The Health Care Manager 19, 65-76.

[31] Lyons S, Duxbury L \& Higgins C (2005) Are gender differences in basic human values a generational phenomenon? Sex Roles 53 (9/10) pp 763-778.

[32] Lyons S, Schweitzer L, Ng E, Kuron L. (2012) Comparing apples to Apples: A qualitative investigation of career mobility patterns across four generations. Career Development International 17: 333-367

[33] Prokopeak, M. (2013). How to Retain Your Millennial Workers. Workforce, 92(9). Retrieved September 30, 2009_http://www.workforce.com/articles/9338- interview-withdan-schwabel-howto-retain-your-millennial-work

[34] Mannheim, K. (1952). The problem of Generations in Mannheim K-Essays on the Sociology of Knowledge. London: RKP.

[35] Murray, K., (2015) Leadership Q \& A. Journal of Nursing Management 47-56

[36] Nelsey, L \& Brownie, S. (2012) Effective leadership, team working and mentoring-Essential elements in promoting generational cohesion in Nursing workforce and retaining Nurses. Collegian 19: $341-354$

[37] O'Sulliva \& Abel, (2007) Research Methods, $5^{\text {Th }}$ Edition, Routledge

[38] Parry, E., \& Urwin P. (2011) Generational differences in work values: A review of theory and evidence. International Journal of Management Review 13 (1), 79-96

[39] Reisenwitz, T. H., \& Iyer, R. (2009). Differences in Generation X and Generation Y: Implications for the Organization and Marketers. The Marketing Management Journal, 19(2), 91103.

[40] Roodin,P., \& Mendelson, M. (2013) Multiple generations at work: Current and future trends. Journal of intergenerational Relationships $11:$ (213-222)

[41] Saab, D. (2015) Using technology to retain baby boomers in the workforce. Computer and Information Science 8:180-185

[42] Shaw, S., \& Fairhurst, D. (2008). Engaging a New Generation of Graduates. Education and Training, 50(5), 366-378. http://dx.doi.org/10.1108/00400910810889057

[43] Tavener, M., Byles J., \& Loxton,D (2014) Research expert perception of the popular Baby Boomer image. Australasian Journal on Ageing 33: 289-306

[44] Twenge, J.M (2010) A review of empirical evidence on generational differences in work attitudes. Journal of Business psychology, 25,201-210

[45] Radford K, et al. (2012). Battle of the decades: Generational differences in the retention of Australian aged care employees. Paper Submitted to the Emerging researchers in ageing Conference 2012.

[46] Ryder, N. (1965). The cohort as a concept in the study of social change. American sociological Review, 30, 843-61.

[47] Shacklock K.H \& Brunetto, Y (2011). The intentions to continue nursing: work variables affecting three nurse generations in Australia. Journal of Advanced Nursing, 68 (1) 136-42.

[48] Saunders, et.al. (2003) Research Methods for Business studies, $3^{\text {rd }}$ Edition, Pearson, Education,Pvt Ltd, Singapore

[49] Smola, K.W., \& Sutton, C.D. (2002). Generational differences: revisiting generational work values for the millennium. Journal of organizational Behaviour, 23(1), 363-82.

[50] Smola, K.W., \& Sutton, C.D. (2002). Generational differences: revisiting generational-work values for the millennium. Journal of organizational Behaviour, 23 (1), 363-82. 
[51] Strauss, W., \& Howe, N. (1992). Generations: the history of America's future, 1584 to 2069. New York: Quill Publishing

[52] Twenge, J. M. (2010). A review of the empirical evidence on generational differences in work attitudes. Journal of Business and Psychology, 25, 201-210. New York, NY.

[53] Umer, M \& Naseem, M.K (2011). Global Journal of Management and Business Research 11 (3) Version 1.0 March 2011

[54] Young A.M \& Hensley, MD (2012). Work values preferences of Generation Y: Performance relationship insights in the Australian Public Service. The international journal of Human Resource Management 27, 1997-2015

[55] Zemke, R., Raines, C., \& Filipczak, B. (2000). Generations at work: Managing the clash of Veterans, Boomers, $X 0$ 